\title{
A COST-EFFECTIVE AND GREEN AQUEOUS SYNTHESIS OF 3-SUBSTITUTED COUMARINS CATALYZED BY POTASSIUM PHTHALIMIDE
}

\author{
Hamzeh Kiyani* and Masoumeh Darzi Daroonkala \\ School of Chemistry, Damghan University, 36715-364 Damghan, Iran
}

(Received July 13, 2014; revised May 14, 2015)

\begin{abstract}
An efficient procedure for the synthesis of various 2-imino-2H-chromene-3-carbonitriles, 2-oxo$2 \mathrm{H}$-chromene-3-carbonitriles as well as 2 -oxo- $2 \mathrm{H}$-chromene-3-carboxylic acids is reported. It has been found that potassium phthalimide (PPI) catalyse the Knoevenagel condensation reaction of salicylaldehydes and activated $\beta$ dicarbonyl compounds efficiently under aqueous conditions at room temperature. This approach provides many merits such as high yields of products, clean, simple work-up, waste free, mild reaction conditions, commercially available organocatalyst, and the use of water as environmentally benign solvent.
\end{abstract}

KEY WORDS: Salicylaldehydes, Potassium phthalimide, 2-Imino-2H-coumarin-3-carbonitrile, 2-Oxo-2Hchromene-3-carbonitrile, 2-Oxo-2H-chromene-3-carboxylic acid

\section{INTRODUCTION}

Coumarin compounds are one of the most common oxygen-containing heterocycles that occurs in a variety of natural products and drugs [1-2]. Many of its derivatives exhibit antimicrobial [3], anticoagulant [4], antitumor [5], antioxidant, and anti-inflammatory [6] activities. Compounds bearing this heterocyclic core are found to possess diverse applications in the area of medicinal chemistry, cosmetics, perfumes, optical brightening agents, additives in food, dyes, supramolecular chemistry as well as laser technologies [7]. Due to the excellent fluorescent capacities of coumarin-containing compounds, some of such compounds were employed as artificial ion receptors, fluorescent probes for monitor timely enzyme activity, pathological, and pharmacological mechanisms [2].

3-Cyanocoumarins, on the other hand, can be transferred to the useful compounds such as amides that exhibit specific inhibitory effects on the $\alpha$-chemotripsin [8] and leukocyte elastase [9]. Coumarin-3-carbonitriles and 2-iminocoumarin-3-carbonitriles are also important intermediates, which are required for the preparation of 3-(4-oxo-3,4-dihydrothieno[2,3d]pyrimidin-2-yl)-2-iminocoumarins [10], 3-imino-benzopyrano[2,3-c]isoxazoles [11] as well as 2-(2-iminocoumarin-3-yl)quinazoline-4(3H)-thiones [12]. 3-Carboxycoumarins are used for the synthesis of cephalosporins [13], modified penicillins [14], and chromene-3-carboxamide derivatives as monoamine oxidase inhibitors [15].

The synthetic methods for the construction of coumarin nucleus have been developed over many decades. The construction of this heterocyclic nucleus is usually performed by several procedures including the von Pechmann [16], Perkin [17], and Wittig [18] reactions. In addition to this, the 3 -substituted coumarins are also prepared by the Knoevenagel condensation of salicylaldehydes with compounds containing active methylene group including Meldrum's acid, maleic acid, malonic acid, malonate esters, malononitrile, or ethyl cyanoacetate [19]. This reaction can be catalyzed by various catalysts such as mesoporous molecular sieve MCM-41 [20], Brønsted acid ionic liquid (BAIL) $\left[\left(\mathrm{CH}_{2}\right)_{4} \mathrm{SO}_{3} \mathrm{HMIM}\right]\left[\mathrm{HSO}_{4}\right]$ [21], HZSM-5 zeolite under microwave irradiation [22], L-proline [23], piperidine [24], $\mathrm{ZrCl}_{4}$ in ionic liquid [25], natural clay [26], Mg-Al hydrotalcite [27], $\mathrm{NaOH}$ [28], basic alumina followed by grinding with $p$ toluenesulphonic acid [29], $\mathrm{Na}_{2} \mathrm{CO}_{3}$ and $\mathrm{NaHCO}_{3}$ [30]. 3-Substituted coumarins can be obtained under phase-transfer catalyzed conditions [31]. Uncatalyzed versions of synthesis of 3-

*Corresponding author. E-mail: hkiyani@du.ac.ir 
substituted coumarines in water under heating [32], microwave [33] or ultrasound irradiation [34] have also been reported in the literature. However, most of these methods are suitable for the preparation of 3-substituted coumarins, but many of them suffer from one or more drawbacks such as organic and inorganic catalysts like piperidine, pyridine, $\mathrm{NaOH}$, ionic liquids, required special apparatus (e.g., microwave and ultrasound irradiation), the use of toxic organic solvents, for example dimethylformamide (DMF) and toluene, and harsh reaction conditions. The development of eco-efficient procedure for the synthesis of 3-substituted coumarins and carrying out organic reactions in water is therefore particularly indispensable.

In recent years, the use of water as the solvent has been considerable. In fact, water has several benefits such as cheapness, safety, ecological friendly, readily available, non-toxic and non-flammable, and so much attractive from the standpoint of economic and environmental [35, 36]. As the part of our study on the catalytic applications of potassium phthalimide (PPI) in organic transformations [37-40], we focused our efforts on the synthesis of 2-oxo-2H-chromene3-carbonitriles, 2-oxo- $2 \mathrm{H}$-chromene-3-carboxylic acids as well as 2-imino-2H-coumarin-3carbonitriles (Scheme 1).

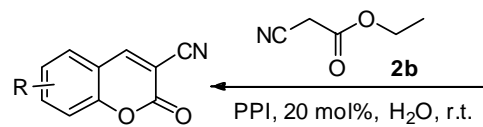

2-Oxo-2H-chromene -3-carbonitrile

4a: $\mathrm{R}=\mathrm{H} ; \mathbf{4 b}: \mathrm{R}=5-\mathrm{Br}$

4c: $\mathrm{R}=3-\mathrm{CH}_{3} \mathrm{O}$

$4 d: \mathrm{R}=4-\left(\mathrm{CH}_{3} \mathrm{CH}_{2}\right)_{2} \mathrm{~N}$

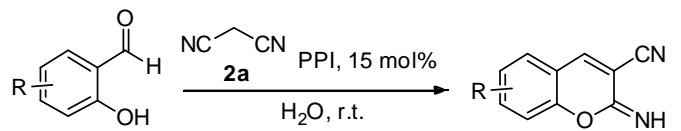

\section{Salicylald ehydes}

1a: $\mathrm{R}=\mathrm{H} ; 1 \mathbf{1 b}: \mathrm{R}=5-\mathrm{Br}$

1c: $\mathrm{R}=3-\mathrm{CH}_{3} \mathrm{O}$

1d: $\mathrm{R}=4-\left(\mathrm{CH}_{3} \mathrm{CH}_{2}\right)_{2} \mathrm{~N}$

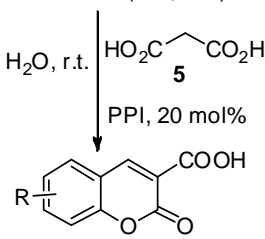

2-Oxo-2H-chromene

-3-carboxylic acids

6a: $\mathrm{R}=\mathrm{H} ; \mathbf{6 b}: \mathrm{R}=5-\mathrm{Br}$

6c: $\mathrm{R}=3-\mathrm{CH}_{3} \mathrm{O}$

6d: $\mathrm{R}=4-\left(\mathrm{CH}_{3} \mathrm{CH}_{2}\right)_{2} \mathrm{~N}$
2-Imino-2H-chromene3-carbonitrile

3a: $\mathrm{R}=\mathrm{H}$; $\mathbf{3 b}: \mathrm{R}=5-\mathrm{Br}$ 3c: $\mathrm{R}=3-\mathrm{CH}_{3} \mathrm{O}$

3d: $\mathrm{R}=4-\left(\mathrm{CH}_{3} \mathrm{CH}_{2}\right)_{2} \mathrm{~N}$

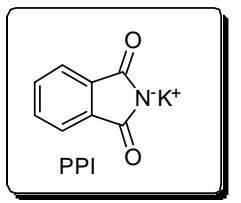

Scheme 1. Synthesis of 2-imino-2H-coumarin-3-carbonitriles (3a-d), 2-oxo-2H-chromene-3carbonitriles (4a-d), and 2-oxo-2H-chromene-3-carboxylic acids (6a-d) in the presence of PPI organocatalyst under aqueous conditions.

\section{RESULTS AND DISCUSSION}

Scheme 1 shows the synthetic pathway for the preparation of targeted compounds 3a-d, 4a-d and 6a-d. At first, in order to find the optimized experimental conditions, the reaction medium as well as catalyst loading was examined. The condensation of salicylaldehyde $1 \mathbf{a}(1 \mathrm{mmol})$ and malononitrile 2a $(1 \mathrm{mmol})$ in the presence of various basic catalysts and solvents was investigated. The results of this study are presented in Table 1. The solvent screening was performed at room temperature and reveals that water is the solvent of choice for this transformation (Table 1, entry 5). It was found that when increasing the amount of the PPI from 5 to 10 , and $20 \mathrm{~mol} \%$, the chemical yield of compound 3a increases from 80 to 88 and $93 \%$, respectively (Table 1, entries 6, 7, and 8). More amounts of the PPI did not improve the yield (Table 1, entry 9). When this reaction was conducted with other basic catalysts such as, sodium ascorbate, sodium citrate, sodium tetraborate, $\mathrm{K}_{2} \mathrm{CO}_{3}$ and $\mathrm{Na}_{2} \mathrm{CO}_{3}$, the yield of the expected 
product was lower. Also, it was observed that a higher reaction temperature $\left(50,75{ }^{\circ} \mathrm{C}\right.$ and reflux) leads to a lower yield. It should be mentioned when the reaction was implemented in the absence of solvent and PPI the yield of the product was low (Table 1, entries 15 and 16).

Table 1. Screening reaction conditions for the synthesis of 2-imino- $2 H$-chromene-3-carbonitrile (3a). ${ }^{a}$

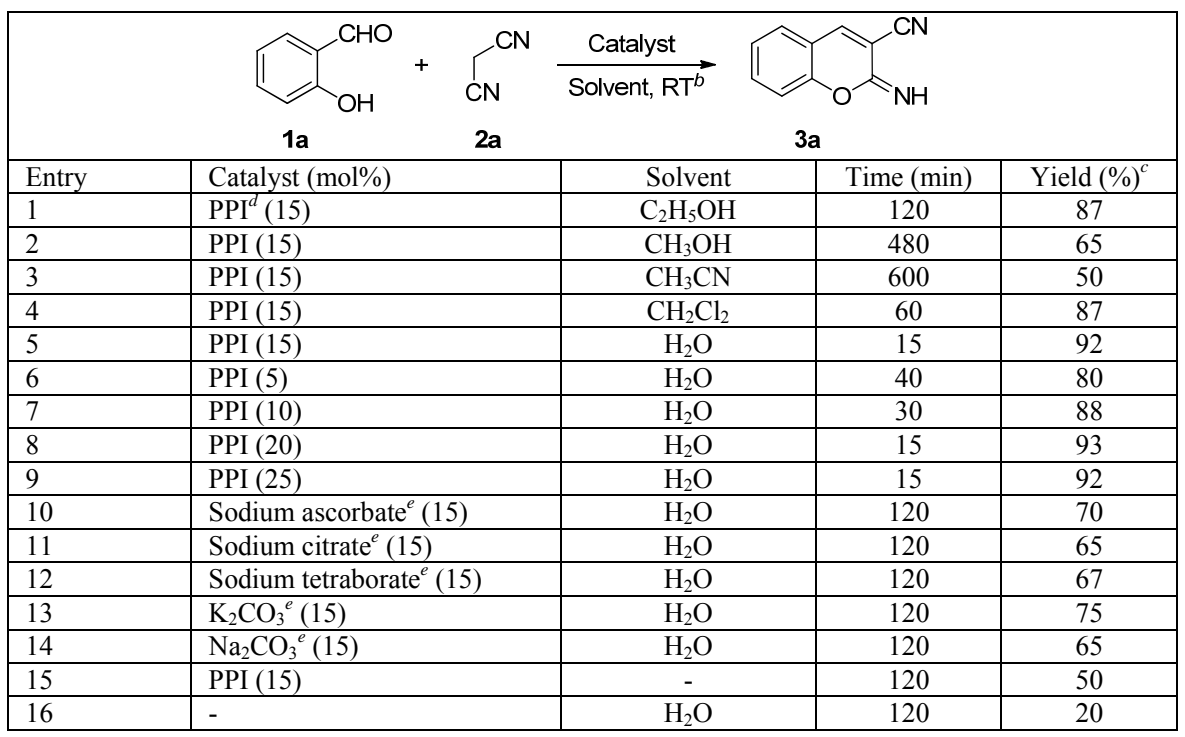

${ }^{a}$ Reaction conditions: salicylaldehyde 1a $(1 \mathrm{mmol})$, malononitrile $(2 \mathrm{a})(1 \mathrm{mmol}) .{ }^{b} \mathrm{Chemical}$ yield were slightly decreased by increasing the temperature to $50,75^{\circ} \mathrm{C}$ and reflux. ${ }^{c}$ Isolated yields. ${ }^{d}$ PPI: Potassium phthalimide. ${ }^{e}$ The yield of product was slightly increased by increasing the catalyst loading (from 15 to 20 and $25 \mathrm{~mol} \%$ ). Also, the reaction in less polar solvents (e.g. $\mathrm{C}_{2} \mathrm{H}_{5} \mathrm{OH}, \mathrm{CH}_{3} \mathrm{OH}, \mathrm{CH}_{3} \mathrm{CN}$, and $\mathrm{CH}_{2} \mathrm{Cl}_{2}$ ) gave $3 \mathrm{a}$ in lower yields.

Under the optimized conditions in hand, the scope and the generality of this method were studied. By changing the salicylaldehyde (1a) to 5-bromo-2-hydroxybenzaldehyde (1b), 2hydroxy-3-methoxybenzaldehyde (1c), and 4-(diethylamino)-2-hydroxybenzaldehyde (1d), the expected products $\mathbf{3 b}, \mathbf{3 c}$, and $\mathbf{3 d}$ were achieved in high yields (Table 2, entries 2, 3, and 4). However, the lower chemical yield of compound 4a (70\%) was achieved on replacement of the malononitrile (2a) with ethyl 2-cyanoacetate (2b).

Also, under the above conditions, the reaction of salicylaldehyde (1a) and malonic acid (5) proceeded and 2-oxo-2H-chromene-3-carboxylic acid (6a) was obtained in lower yield (65\%) rather than the expected yield. In these cases, catalyst loading was increased from 15 to 20 mol\%, and chemical yields of compounds $4 \mathbf{a}$ and $\mathbf{6 a}$ increase to 90 and $88 \%$, respectively (Table 2, entries 5 and 9). Our investigations clarified that in this case the best results can be obtained under the conditions shown in Scheme 2.

As shown in Table 2, some trends in the reactions of salicylaldehydes (1a-d) with compounds containing active methylene group (2a, b and 5) were noted, that is, the yields were slightly affected by the substituents of the investigated aldehydes. Plausible reaction mechanism for this condensation is shown in Scheme 3. On the basis of the chemistry of the Knoevenagel condensation, it is reasonable to assume that anion $\mathbf{A}$ was formed by removal proton from active methylene containing compounds $(\mathbf{2 a - b}, \mathbf{5})$ with potassium phthalimide $\left(\mathrm{P}^{+} \mathrm{PI}^{-}\right)$. Then intermediate oxyanion $\mathbf{B}$ was formed via the reaction of aryl aldehydes 1a-d and anion $\mathbf{A}$, followed elimination of water leading to Knoevenagel adducts $\mathbf{D}, \mathbf{E}$ and $\mathbf{F}$. Then intramolecular nucleophilic cyclization ( $\mathrm{O}$-attack) take place on the electrophilic carbon and thus intermediates 
$\mathbf{G}, \mathbf{H}$ and $\mathbf{J}$ were formed. Intermediate $\mathbf{G}$ undergoes a proton transfer, and the 2-imino- $2 \mathrm{H}$ coumarin-3-carbonitriles 3a-d are formed. Followed by proton transfer, intermediates $\mathbf{I}$ and $\mathbf{K}$ are formed, which then experienced deethanolizaion and dehydration under the reaction conditions and give the desired compounds $4 \mathbf{a}-\mathbf{d}$ and $\mathbf{6 a - d}$.

Table 2. Synthesis of 3 -substituted coumarins $\mathbf{3 , 4}$ and $\mathbf{6}$. $^{\mathrm{a}}$

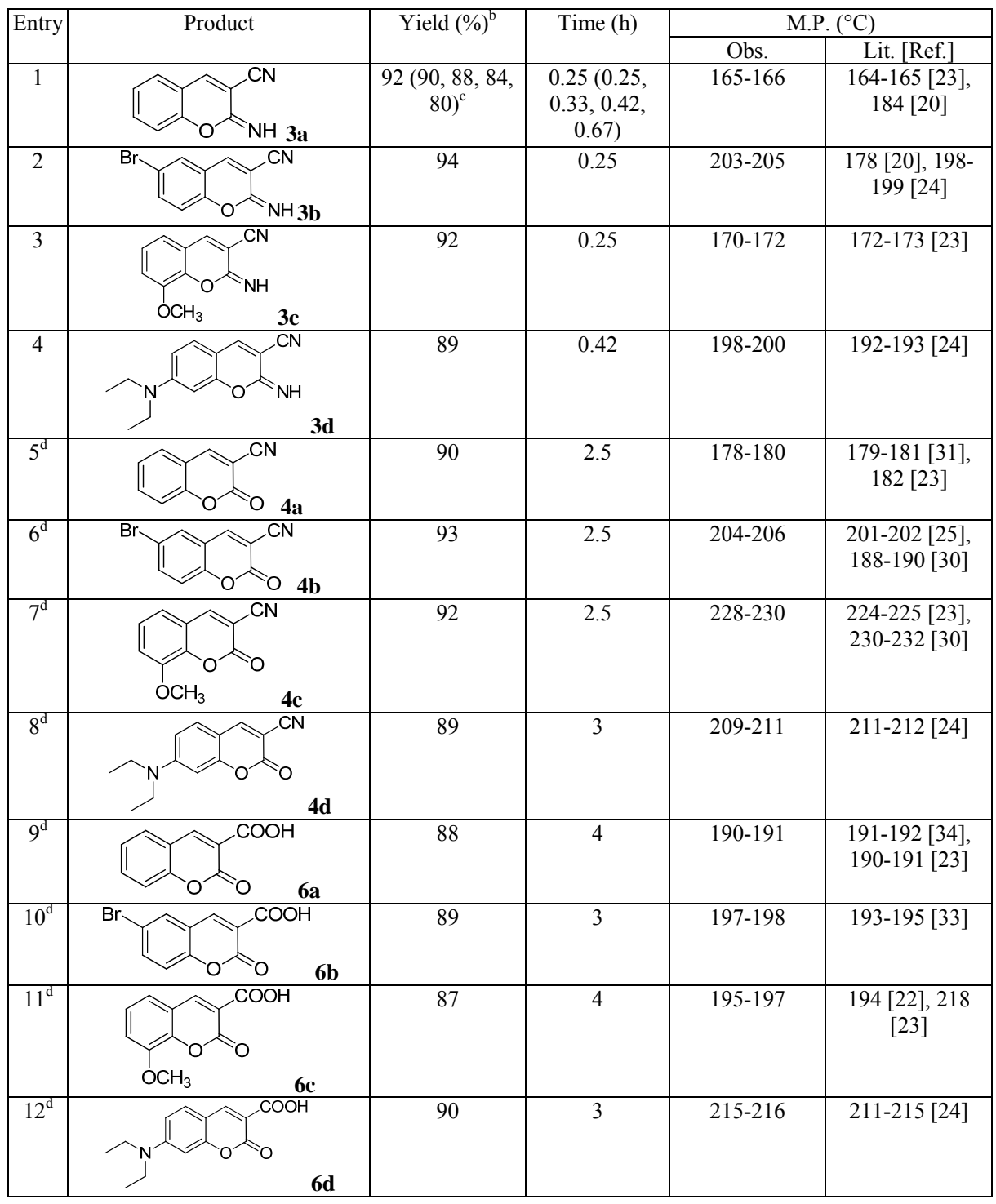

${ }^{a}$ Reaction conditions: 2-hydroxybenzaldehyde 1a-d $(1 \mathrm{mmol})$, active methylene compound 2a,b, 5 ( 1 mmol), PPI, $\mathrm{H}_{2} \mathrm{O}(4 \mathrm{~mL})$, stirring at room temperature. ${ }^{\mathrm{b}}$ Isolated yields. ${ }^{\mathrm{c}}$ Catalyst was reused four times. ${ }^{\mathrm{d}}$ Compounds (4a-d and 6a-d) were obtained by using $20 \mathrm{~mol} \%$ of catalyst loading. 


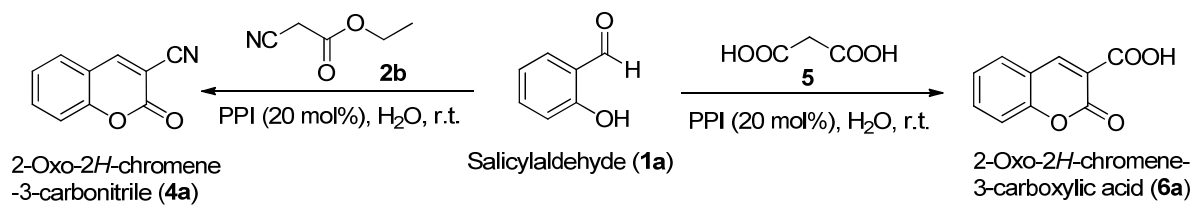

Scheme 2. Optimized conditions for $\mathbf{4 a}$ and $\mathbf{6 a}$.
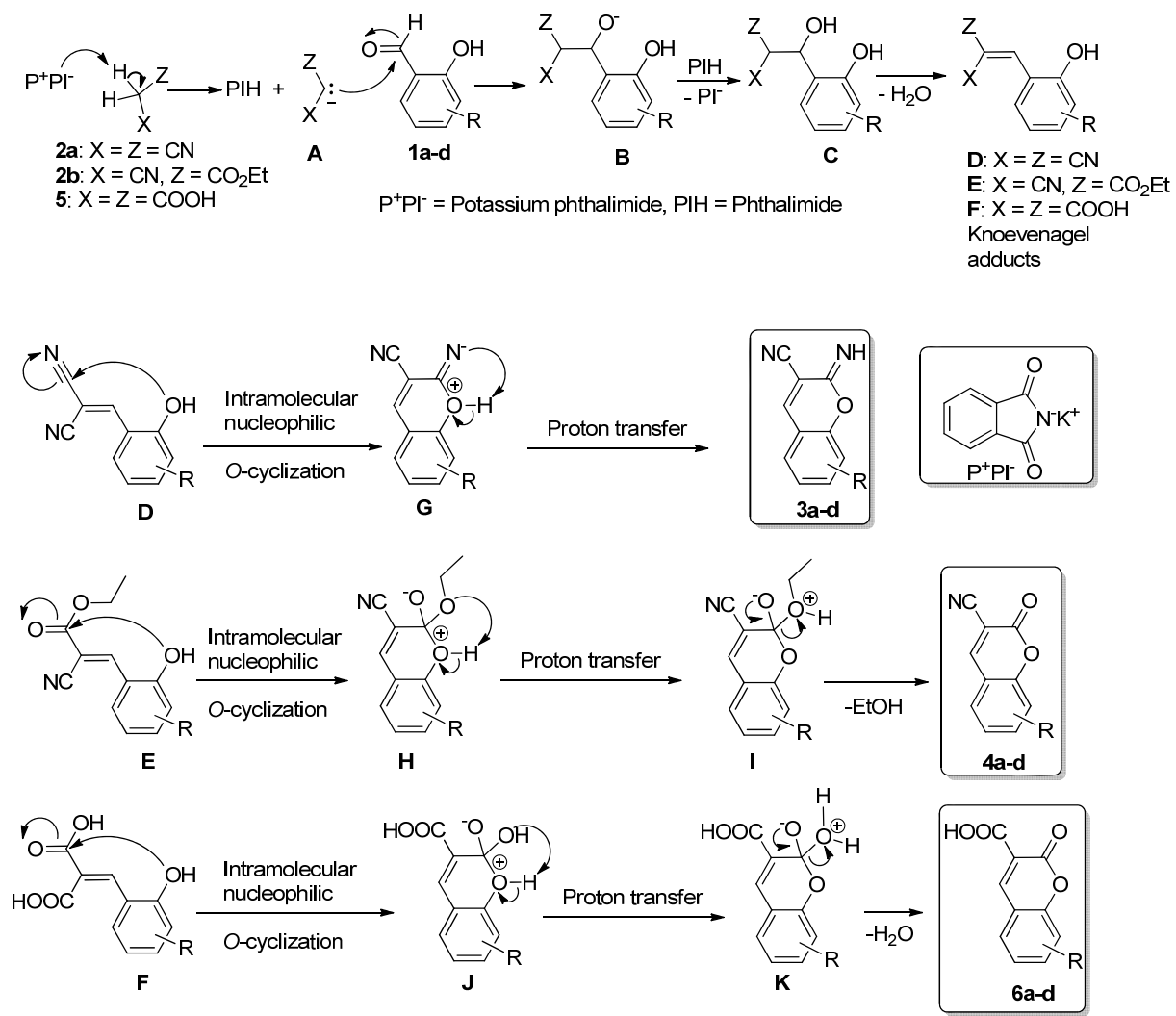

Scheme 3. The proposed mechanisms for formation of title compounds (3a-d, 4a-d and 6a-d).

The reuse and recycling of PPI was investigated. After filtration of the reaction mixture to separate the product (3a), the filtrate was charged with the same substrates and was reused for four cycles, which afforded yields similar to those achieved in the first run, despite the fact that increases in reaction time were detected (Table 2, entry 1 ).

To show the efficiency of this method, we compared our results obtained from synthesis of 2-imino- $2 H$-chromene-3-carbonitrile (3a), 2-oxo- $2 H$-chromene-3-carbonitrile (4a), and 2-oxo$2 \mathrm{H}$-chromene-3-carboxylic acid (6a) in the presence of PPI with other results reported in the literature. As is apparent from Table 3, this method avoids the disadvantages of other 
procedures, for example long reaction times, high temperature, ionic liquids, required special apparatus (e.g., microwave and ultrasound irradiation), and using organic solvents.

Table 3. Comparison of some of the results obtained by the condensation of 2-hydroxybenzaldehyde with malononitrile, ethyl cyanoacetate, or malonic acid in the presence of PPI with those obtained by use of other catalysts.

\begin{tabular}{|c|c|c|c|c|c|c|c|}
\hline \multirow{2}{*}{ Catalyst (mol\% or $\mathrm{mg}) /$ conditions } & & & & & & & \multirow[t]{2}{*}{ Ref. } \\
\hline & Time $(\mathrm{h})$ & Yield (\%) & Time $(\mathrm{h})$ & Yield (\%) & Time $(\mathrm{h})$ & Yield (\%) & \\
\hline MCM-41 (10 mg)/CH 3 CN, $\mathrm{RT}^{\mathrm{a}}$ & $2 \mathrm{~h}$ & 94 & - & - & - & - & {$[20]$} \\
\hline $\mathrm{NaHCO}_{3}(0.05 \mathrm{M}, 1.5 \mathrm{~mL}) / \mathrm{RT}$ & $4.5-24$ & 86 & - & - & - & - & [30] \\
\hline $\mathrm{Na}_{2} \mathrm{CO}_{3}(0.05 \mathrm{M}, 1.5 \mathrm{~mL}) / \mathrm{RT}$ & $2-24$ & 90 & - & - & - & - & [30] \\
\hline $\begin{array}{l}\text { Mg-Al hydrotalcite }(10 \% \\
\text { w/w }) / \text { toluene }(30 \mathrm{~mL}), 80^{\circ} \mathrm{C}\end{array}$ & - & - & 4 & 93 & - & - & [27] \\
\hline $\begin{array}{l}\left(n-\mathrm{C}_{4} \mathrm{H}_{9}\right)_{4} \mathrm{~N}\left(\mathrm{HSO}_{4}\right)(30 \\
\mathrm{mol} \%) / \mathrm{K}_{2} \mathrm{CO}_{3}, \text { benzene, RT }\end{array}$ & - & - & $30 \mathrm{~min}$ & 80 & - & - & {$[31]$} \\
\hline $\mathrm{NaOH}(10 \mathrm{~mol} \%) / \mathrm{H}_{2} \mathrm{O}, 75^{\circ} \mathrm{C}$ & - & - & 24 & - & - & - & [28] \\
\hline $\mathrm{ZrCl}_{4}(15 \mathrm{~mol} \%) /[\mathrm{bmim}] \mathrm{BF}_{4}, \mathrm{RT}$ & - & - & $35 \mathrm{~min}$ & 83 & - & - & [25] \\
\hline Natural clay $(100 \mathrm{mg}) /$ microwave & - & - & - & - & $4 \mathrm{~min}$ & 82 & [26] \\
\hline No catalyst $/ \mathrm{H}_{2} \mathrm{O}$, reflux & - & - & - & - & 10 & 93 & {$[32]$} \\
\hline PPI $(20 \mathrm{~mol} \%) / \mathrm{H}_{2} \mathrm{O}, \mathrm{RT}$ & $15 \mathrm{~min}$ & 92 & 2.5 & 90 & 4 & 88 & {$\left[{ }^{b}\right]$} \\
\hline
\end{tabular}

${ }^{\mathrm{a}}$ Room temperature. ${ }^{\text {PPresent }}$ work.

\section{CONCLUSIONS}

In summary, PPI have been used as an effective reagent and solid basic organocatalyst for simple and efficient synthesis of 2-imino- $2 \mathrm{H}$-chromene-3-carbonitriles, 2-oxo- $2 \mathrm{H}$-chromene-3carbonitriles, and 2-oxo- $2 \mathrm{H}$-chromene-3-carboxylic acids. The process has several benefits, for example ease of using and handling of the catalyst, mild reaction conditions, simple experimental technique, and use of a cheap and available catalyst. Moreover, this procedure avoids problems associated with organic solvents; these economic and environmental merits make it a valuable and eye-catching approach. The effectiveness of this convenient technique is comparable with that of existing methods for synthesis of 3 -substituted coumarins.

\section{EXPERIMENTAL}

All the reagents and chemicals were obtained from commercial sources and used without further purification. Melting points were measured on a Buchi 510 melting point apparatus and are uncorrected. IR spectra were recorded with a Shimadzu FT-IR 8300 Spectrophotometer using $\mathrm{KBr}$ pellets technique. ${ }^{1} \mathrm{H}$ NMR and ${ }^{13} \mathrm{C}$ NMR spectra were recorded at ambient temperature using a Bruker Avance DRX-300 MHz spectrophotometer using dimethylsulfoxide (DMSO- $d_{6}$ ) or $\mathrm{CDCl}_{3}$ as the solvent and TMS as an internal standard. The purity of synthesized compounds as well as a progress of the reactions was monitored by thin layer chromatography (TLC) analysis on Merck pre-coated silica gel $60 \mathrm{~F}_{254}$ aluminum sheets, visualized by UV light.

General procedure for the PPI-promoted synthesis of title compounds (3, 4 and 6)

Salicylaldehyde derivative (1 mmol), active methylene compound ( $1 \mathrm{mmol})$ and PPI were added to $5 \mathrm{~mL}$ of water and the reaction mixture was stirred at room temperature for the appropriate time (Table 2). After completion of the reaction (as indicated by TLC analysis), the mixture was filtered to separate the precipitated product, which was further purified by rinsing with cold 
Green aqueous synthesis of 3-substituted coumarins catalyzed by potassium phthalimide 455

reaction solvent. The filtrate was charged with the same substrates and was reused for successive cycles. The products were identified by comparison with authentic samples or NMR data.

\section{Selected spectral data}

7-Diethylamino-2-imino-2H-chromene-3-carbonitrile (3d). IR (KBr) $\left(v_{\max }, \mathrm{cm}^{-1}\right): 3300,2215$, $1645,1625,1570 ;{ }^{1} \mathrm{H}$ NMR (300 MHz, DMSO-d $\left.d_{6}\right) \delta: 8.21(\mathrm{~s}, 1 \mathrm{H}, \mathrm{NH}) ; 8.05$ (s, $\left.1 \mathrm{H}, \mathrm{CH}\right), 7.32$ $(\mathrm{d}, J=8.7 \mathrm{~Hz}, 1 \mathrm{H}, \mathrm{ArH}), 6.59(\mathrm{dd}, J=8.8 \mathrm{~Hz}, 2.4 \mathrm{~Hz}, 1 \mathrm{H}, \mathrm{ArH}), 6.29(\mathrm{~d}, J=2.1 \mathrm{~Hz}, 1 \mathrm{H}, \mathrm{ArH})$, 3.43 (q, $\left.J=7.2 \mathrm{~Hz}, 4 \mathrm{H}, \mathrm{CH}_{2}\right), 1.15\left(\mathrm{t}, J=7.2 \mathrm{~Hz}, 6 \mathrm{H}, \mathrm{CH}_{3}\right) ;{ }^{13} \mathrm{C}$ NMR $\left(75 \mathrm{MHz}, \mathrm{DMSO}-d_{6}\right) \delta$ : $156.3 ; 153.2,152.7,146.4,130.6,116.7,108.2,106.0,96.2,94.3,44.2,12.3 \mathrm{ppm}$.

2-Oxo-2H-chromene-3-carbonitrile (4a). IR (KBr) $\left(v_{\max }, \mathrm{cm}^{-1}\right): 3042,2224,1770,1725,1682$, 1605, 1560; ${ }^{1} \mathrm{H}$ NMR $\left(300 \mathrm{MHz}, \mathrm{CDCl}_{3}\right) \delta: 8.35(\mathrm{~s}, 1 \mathrm{H}, \mathrm{CH}), 8.35(\mathrm{~s}, 1 \mathrm{H}), 7.64(\mathrm{t}, J=7.5 \mathrm{~Hz}$, $1 \mathrm{H}, \mathrm{ArH}), 7.59(\mathrm{~d}, J=7.6 \mathrm{~Hz}, 1 \mathrm{H}, \mathrm{ArH}), 7.36-7.44(\mathrm{~m}, 2 \mathrm{H}, \mathrm{ArH}) ;{ }^{13} \mathrm{C} \mathrm{NMR}\left(75 \mathrm{MHz}, \mathrm{CDCl}_{3}\right) \delta$ : $159.4,156.5,135.6,130.4,128.3,125.2,120.3,118.5,114.5,101.8 \mathrm{ppm}$.

2-Oxo-6-bromo-2H-chromene-3-carbonitrile (4b). IR (KBr) $\left(v_{\max }, \mathrm{cm}^{-1}\right)$ : 3025, 2223, 1732, $1641,1618,1600 ;{ }^{1} \mathrm{H}$ NMR $\left(300 \mathrm{MHz}, \mathrm{CDCl}_{3}\right) \delta: 8.20(\mathrm{~s}, 1 \mathrm{H}, \mathrm{CH}), 8.01(\mathrm{~d}, J=9.0 \mathrm{~Hz}, 1 \mathrm{H}$, $\mathrm{ArH}), 7.62(\mathrm{~s}, 1 \mathrm{H}, \mathrm{ArH}), 7.34(\mathrm{~d}, J=8.7 \mathrm{~Hz}, 1 \mathrm{H}, \mathrm{ArH}) ;{ }^{13} \mathrm{C} \mathrm{NMR}\left(75 \mathrm{MHz}, \mathrm{CDCl}_{3}\right) \delta: 155.2$, $152.1,137.2,131.5,119.2,118.5,117.1,116.6,114.1,102.9 \mathrm{ppm}$.

7-Diethylamino-2-oxo-2H-chromene-3-carboxylic acid (6d). IR ( $\mathrm{KBr})\left(v_{\max }, \mathrm{cm}^{-1}\right): 3449,3024$, 2981, 1741, 1662, 1610, 1569; ${ }^{1} \mathrm{H}$ NMR $\left(300 \mathrm{MHz} \mathrm{CDCl}_{3}\right) \delta: 11.2(\mathrm{~s}, 1 \mathrm{H}, \mathrm{OH}), 8.64(\mathrm{~s}, 1 \mathrm{H}$, $\mathrm{CH}), 7.46(\mathrm{~d}, J=9.0 \mathrm{~Hz}, 1 \mathrm{H}, \mathrm{ArH}), 6.73(\mathrm{dd}, J=2.4,9.0 \mathrm{~Hz}, 1 \mathrm{H}, \mathrm{ArH}), 6.52$ (d, $J=2.2 \mathrm{~Hz}, 1 \mathrm{H}$, $\mathrm{ArH}), 3.51$ (q, $\left.J=7.1 \mathrm{~Hz}, 4 \mathrm{H}, \mathrm{CH}_{2}\right), 1.29\left(\mathrm{t}, J=7.1 \mathrm{~Hz}, 6 \mathrm{H}, \mathrm{CH}_{3}\right) ;{ }^{13} \mathrm{C} \mathrm{NMR}\left(75 \mathrm{MHz}, \mathrm{CDCl}_{3}\right)$ $\delta: 165.4,164.4,157.8,153.7,150.2,132.1,111.0,108.5,105.9,97.2,45.5,12.6 \mathrm{ppm}$.

\section{ACKNOWLEDGEMENT}

The authors are thankful to the Research Council of Damghan University.

\section{REFERENCES}

1. Murray, R.D.H.; Mendez, J.; Brown, S.A. The Natural Coumarins: Occurrence, Chemistry and Biochemistry, Wiley: New York; 1982.

2. Peng, X.-M.; Damu, G.L.V.; Zhou, C.-H. Curr. Pharm. Des. 2013, 19, 3884.

3. Smyth, T.; Ramachandran, V.N.; Smyth, W.F. Int. J. Antimicrob. Ag. 2009, 33, 421.

4. Kidane, A.G.; Salacinski, H.; Tiwari, A.; Bruckdorfer, K.R.; Seifalian, A.M. Biomacromolecules 2004, 5, 798.

5. Draoui, N.; Schicke, O.; Fernandes, A.; Drozak, X.; Nahra, F.; Dumont, A.; Douxfils, J.; Hermans, E.; Dogné, J.M.; Corbau, R.; Marchand, A.; Chaltin, P.; Sonveaux, P.; Feron, O.; Riant, O. Bioorg. Med. Chem. 2013, 21, 7107.

6. Melagraki, G.; Afantitis, A.; Igglessi-Markopoulou, O.; Detsi, A.; Koufaki, M.; Kontogiorgis, C.; Hadjipavlou-Litina, D.J. Eur. J. Med. Chem. 2009, 44, 3020.

7. O'Kennedy, R.; Thornes, R.D. Coumarins: Biology, Applications and Mode of Action, John Wiley and Sons: Chichester; 1997.

8. Doucet, C.; Pochet, L.; Thierry, N.; Pirotte, B.; Delarge, J.; Reboud-Ravaux, M. J. Med. Chem. 1999, 42, 4161. 
9. Pochet, L.; Doucet, C.; Schynts, M.; Thierry, N.; Boggetto, N.; Pirotte, P.; Jiang, K.Y.; Masereel, B.; de Tullio, P.; Delarge, J.; Reboud-Ravaux, M. J. Med. Chem. 1996, 39, 2579.

10. Shynkarenko, P.E.; Vlasov, S.V.; Kovalenko, S.M.; Shishkina, S.V.; Shishkin, O.V.; Chernykh, V.P. J. Heterocycl. Chem. 2010, 47, 800.

11. Kammoun, M.; Turki, H.; Ammar, H.; El Gharbi, R. Synth. Commun. 2012, 42, 1677.

12. Shynkarenko, P.E.; Vlasov, S.V.; Kovalenko, S.M.; Chernykh, V.P. J. Sulfur Chem. 2010, 31, 447.

13. Bonsignore, L.; Cottiglia, F.; Elkhaili, H.; Jehl, F.; Lavagna, S.M.; Loy, G.; Manna, F.; Monteil, H.; Pompei, D.; Secci, D. Farmaco 1998, 53, 425.

14. Bonsignore, L.; De Logu, A.; Loy, G.; Lavagna, S.M.; Secci, D. Eur. J. Med. Chem. 1994, 29, 479.

15. Pan, Z.-X.; He, X.; Chen, Y.-Y.; Tang, W.-J.; Shi, J.-B.; Tang, Y.-L.; Song, B.-A.; Li, J.; Liu, X.-H. Eur. J. Med. Chem. 2014, 80, 278.

16. Pechmann, H.; Duisberg, C. Chem. Ber. 1884, 17, 929.

17. Johnson, J.R. Org. React. 1942, 1, 210.

18. Yavari, I.; Hekmat-Shoar, R.; Zonouzi, A. Tetrahedron Lett. 1998, 39, 2391.

19. Jones, G. Org. React. 1967, 15, 204.

20. Heravi, M.M.; Poormohammad, N.; Beheshtiha, Y.S.; Baghernejad, B.; Malakooti, R. Bull. Chem. Soc. Ethiop. 2010, 24, 273.

21. Heravi, M.M.; Ansari, P.; Saeedi, M.; Karimi, N.; Tavakoli-Hosseini, N. Bull. Chem. Soc. Ethiop. 2011, 25, 315.

22. Heravi, M.M.; Hekmatshoar, R.; Emamgholizadeh, M. Phosphorus, Sulfur Silicon Relat. Elem. 2004, 179, 1893.

23. Karade, N.N.; Gampawar, S.V.; Shinde, S.V.; Jadhav, W.N. Chin. J. Chem. 2007, 25, 1686.

24. Volmajer, J.; Toplak, R.; Leban, I.; Le Marechal, A.M. Tetrahedron 2005, 61, 7012.

25. Valizadeh, H.; Mahmoodian, M.; Gholipour, H. J. Heterocycl. Chem. 2011, 48, 799.

26. Bandgar, B.P.; Uppalla, L.S.; Kurule, D.S. Green Chem. 1999, 1, 243.

27. Ramani, A.; Chanda, B.M.; Velu, S.; Sivasanker, S. Green Chem. 1999, 1, 163.

28. Zhang, M.; Zhang, A.-Q. Synth. Commun. 2004, 34, 4531.

29. Kumar, S. Green Process. Synth. 2014, 3, 223.

30. Costa, M.; Areias, F.; Abrunhosa, L.; Venancio, A.; Proenca, F. J. Org. Chem. 2008, 73, 1954.

31. Seema, Kumar, S.; Makrandi, J.K. Indian J. Chem. 2005, 44B, 1307.

32. Maggi, R.; Bigi, F.; Carloni, S.; Mazzacani, A.; Sartori, G. Green Chem. 2001, 3, 173.

33. Sharma, D.; Kumar, S.; Makrandi, J.K. Chem. Sci. Trans. 2013, 2, 403.

34. Du, J.-L.; Li, L.-J.; Zhang, D.-H. E-J. Chem. 2006, 3, 1.

35. Lindström, U.M. (Ed.) Organic Reactions in Water: Principles, Strategies and Applications, Blackwell Publishing: Oxford, U.K.; 2007.

36. Mosaddegh, E.; Hassankhani, A. Bull. Chem. Soc. Ethiop. 2012, 26, 461.

37. Kiyani, H.; Ghorbani, F. J. Saudi Chem. Soc. 2014, 18, 689.

38. Kiyani, H.; Ghorbani, F. Chem. Pap. 2014, 68, 1104.

39. Kiyani, H.; Ghiasi, M. Res. Chem. Intermed. 2015, 41, 5177.

40. Kiyani, H.; Ghiasi, M. Chin. Chem. Lett. 2014, 25, 313. 